Article

\title{
A City Profile of Malaga: The Role of the Port-City Border throughout Historical Transformations
}

\author{
María J. Andrade ${ }^{1,2, *}$, João Pedro Costa ${ }^{2}$, Eduardo Jiménez-Morales ${ }^{1}$ and Jonathan Ruiz-Jaramillo ${ }^{1}$ \\ ${ }^{1}$ Departamento Arte y Arquitectura, Malaga School of Architecture, Universidad de Málaga, Spain; \\ E-Mails: mjandrade@uma.es (M.J.A.), eduardo_jm@uma.es (E.J.-M.), jonaruizjara@uma.es (J.R.-J.) \\ ${ }^{2}$ CIAUD, Centro de Investigação em Arquitetura, Urbanismo e Design, Lisbon School of Architecture, \\ Universidade de Lisboa, Portugal; E-Mail: jpc@fa.ulisboa.pt \\ * Corresponding author
}

Submitted: 15 February 2021 | Accepted: 27 March 2021 | Published: 27 July 2021

\begin{abstract}
The relationships Malaga has established with its port have changed over the centuries, conjuring up a variety of scenarios and circumstances. The past and present are closely linked phenomena in this case study where the porosity of the port-city fabric has marked the city's development and constitutes a key issue in the current and future challenges it faces. Malaga provides a particularly interesting example of a post-industrial city that has reopened its port to its inhabitants' acclaim while maintaining port activity. However, the growth tourism has seen in recent years has come to dominate the local economy. Cruise ships have taken on a significant role and have brought about important changes in the dynamics and flows between the port and the city, unsettling the balance between the two. This profile explores port-city development through the lens of boundaries and flows, demonstrating how their dynamics have determined Malaga's spatial, functional, and social development over time and how they continue to do so to this day. This article reviews the transformations the city has undergone and its future opportunities to achieve a balanced and sustainable port-city relationship.
\end{abstract}

\section{Keywords}

Malaga; porosity; port city; waterfront

\section{Issue}

This article is part of the issue "Planning for Porosity: Exploring Port City Development through the Lens of Boundaries and Flows" edited by Carola Hein (Delft University of Technology, The Netherlands).

(C) 2021 by the authors; licensee Cogitatio (Lisbon, Portugal). This article is licensed under a Creative Commons Attribution 4.0 International License (CC BY).

\section{Introduction}

Porosity, as described by Walter Benjamin in the chapter dedicated to Naples in his book "In One Way Street and Other Writings" (Benjamin, 1985), provides a reference to understand urban space as a result of processes of appropriation and encounter (Sennett, 1995). It articulates the previously established relations between place and function. In this sense, porosity considers spontaneity as a permanent challenge to the limits between urban spaces and times, simultaneously connecting and separating neighbouring zones and events through time.
The porosity of the port-city fabric has marked the development of the port city of Malaga and constitutes a key issue in the current and future challenges it faces. Exploring port-city development through the lens of boundaries and flows can demonstrate how the dynamics of these over time have been a determining factor in Malaga's spatial, functional, and social development and how they continue to be so to this day. By assessing issues like industrial heritage, the historic city centre's public neighbourhood spaces, new functional interactions and the mix of memories and meanings, along with other topics, it can be seen that this port city's present and future development opportunities are to be found 
in the permeability established in a porous dynamic border between the port and the city.

From the viewpoint of urban historiography, which has become increasingly specialised since the 1960s and an academic discipline in its own right, the analysis of the history of urban phenomena has produced a broad range of topics of study that has been approached from a sectoral perspective by a multitude of disciplines, including architecture, geography, sociology, political science, economy, and anthropology. This disciplinary dispersion is a direct result of the physical and social complexity of the urban phenomena (Harvey, 1973), and obstructs any holistic methodological approach to the subject when trying to incorporate its several dimensions. The article combines historiographical methods with spatial analysis and urban morphology, as a technique to address complex urban processes (Guardia, Monclús, \& Oyón, 1996) and an indispensable tool to spatial planning applied in planning historiography (Kwak, 2017). According to Izaskun Landa (2020), the first category of analysis addresses the historical process of construction of the city, focusing on its space and morphology. The second refers to the sociocultural processes that take place in the city as a place where economic, cultural, political, and religious events occur without considering its spatial variable. Lastly, the third school of thought associates urban sociocultural processes with the space in which they take place. In other words, it correlates the location of activities in urban spaces and these are in turn correlated with their evolution over time. An association of the sociocultural dimension of the city with the physical and spatial dimensions serves as the methodological basis for this article, based on the use of geo-historical spatial mapping as an analytical tool (Hein \& van Mil, 2020), allowing the evaluation of how the levels of porosity in the port-city interface have changed over time (Schubert, 2017).

In this regard, the importance and impact of port activity as a highly significant socio-cultural factor in understanding urban historiography is unquestionable, even more so when we consider that the majority of the great historical cities are port cities. The sea, and by extension rivers, have shaped them over time, acting as a route of cultural exchange, as well as for population and merchandise flows, thereby forging a plural multifaceted place where diverse landscapes and environments from different periods coexist (Braudel, 1980). The nature of the port-city relationship has changed throughout history and has resulted in different scenarios and circumstances. This relationship constitutes one of the most important paradigms for contemporary cities, since it brings together a close spatial association with the utmost functional interdependence, as Hoyle (2000) points out. There is no doubt that ports, as infrastructures of exchange between the sea and land (Grindlay Moreno, 2017), have evolved to adapt to changes in technology and trade and have at the same time transformed their relationship with cities.
Hence, there are two key moments in the historiography of port-cities: the industrial and post-industrial periods. These periods also marked a structural change in the society of the era, understood as referring to the territorial change that resulted from an alteration in the logistics of production (Costa, 2007a).

Moreover, authors such as James Bird (1963), Brian Hoyle (2000), or Han Meyer (1999) refer to the preindustrial period as a key one to understanding the subsequent dynamics, proposing interpretative schemes to better explain this complex reality. Bird (1963) describes the observed changes in space and time through the definition of three phases: the initial settlement phase; the development and expansion of activities phase; and the specialisation and port areas reconversion phase (Figure 1a). Hoyle (2000) proposes six stages: the preindustrial period; the industrial period; and the postindustrial period, which comprehends four dynamics, balancing between the expansion of port activity, and the redevelopment of former port areas, reincreasing port-city integration (Figure 1c). Meyer (1999) defines four moments, the first three similar to the Bird's Anyport, adding a fourth period with the complex port's articulation and the advanced dysregulation, particularly evident in the large port-cities (Figure 1b). As such, a synthesis definition of three large periods of port-city can be accepted (the preindustrial, the industrial, and the post-industrial phases), allowing to address the case study, also referring to the 'medium port-city' proposed by Ducruet and Lee (2006; Figure 1d).

As Meyer (1999) affirms, ports had already distanced themselves from cities in the industrial period, forsaking the close relationship of the pre-industrial period as a storage and distribution centre for merchandise within the walled enclosure. At this point, they were converted into industrial or 'transit' ports (Meyer, 1999). Due to the modernisation of ports, the port-city dichotomy would increase until they became two independent and functionally autonomous realities. The city's trade and industrial fabric would be progressively replaced by another fabric based on tourism and real estate, while the port maintained its separate autonomous function. Schubert (2017) also asserts that all seaport cities have structural similarities, being a functional and spatial unit until the beginning of the 19th century, and later they spatially separated and assumed different institutional responsibilities. Meyer (1999) himself describes this period as an industrial port-functional city,' lasting until practically the end of the 20th century. Subsequently, in the post-industrial period, cities would rediscover their ports as part of the urban landscape, and in turn, cities would be discovered by ports as a potential asset, first as a logistics and telecommunications centre, and later as a tourist attraction for cruise tourism. This period spans from the end of the 20th century to the present.

In the case study at hand, the first period runs from the 8 th century $\mathrm{BC}$ to the middle of the 19th century, 

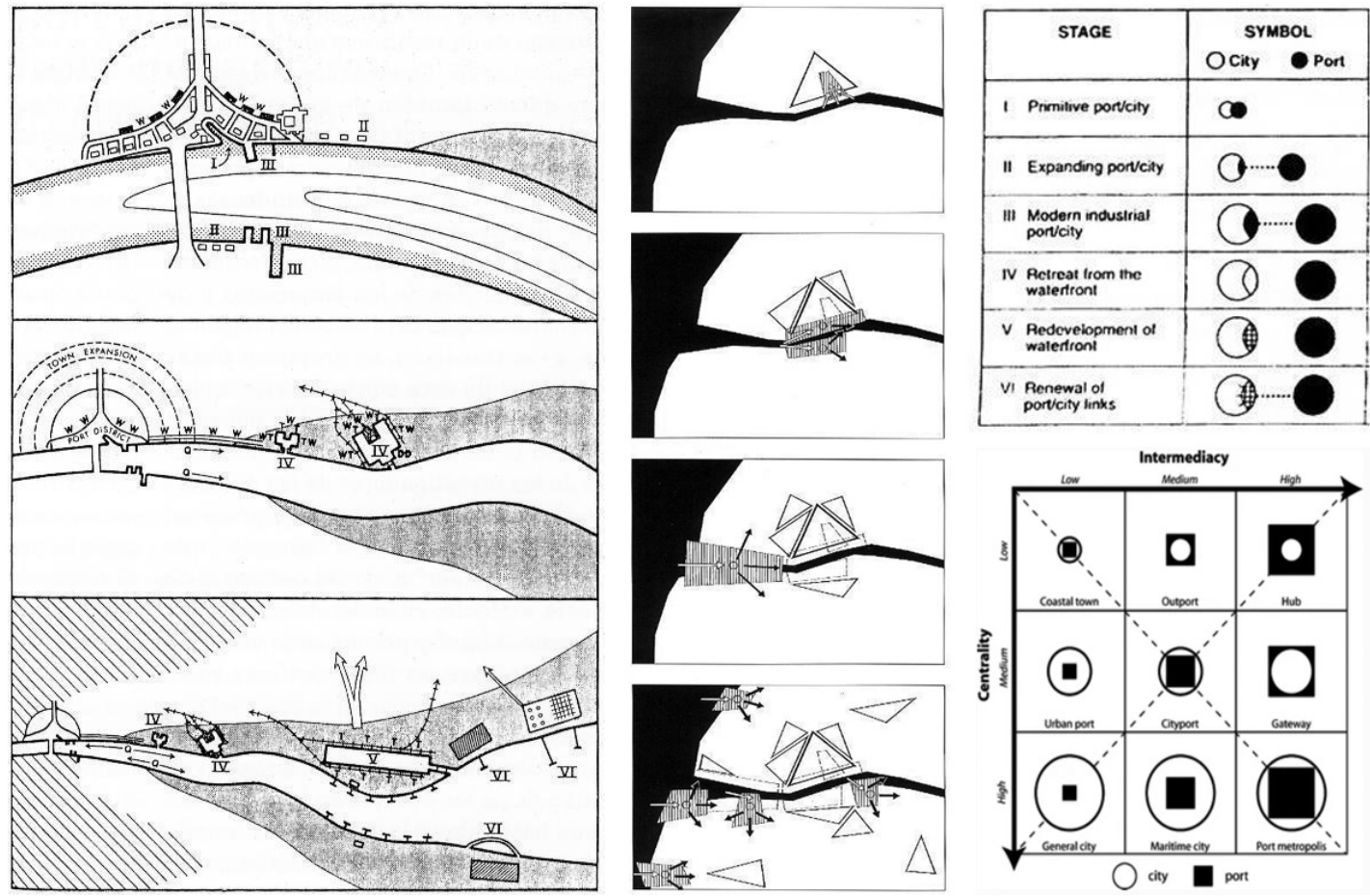

Figure 1. Port-city dynamics. From left to right and from top to bottom: a) Anyport (Bird, 1963, pp. 29, 31, 33); b) Historical port-city evolution (Meyer, 1999, p. 23); c) Development dynamics of the port-city interface (Hoyle, 2000, p. 405); and d) Matrix of port-city relations (Ducruet \& Lee, 2006, p.109).

a considerable period that can be divided into two critical periods of the port-city relationship, and which is especially marked by the demolition of the medieval ramparts. The second period revolves around industrialisation, with Malaga being one of the few Spanish examples of significant industrial activity along the coastline, along with Bilbao and Barcelona (Alemany, 1991, 2010). At the beginning of the 20th century, this activity was replaced by another kind of industry: tourism. The Costa del Sol is one of the most important areas in Spain for beach holidays, and Malaga, as its main hub, has been considered a tourist destination since the 1930s (Barke

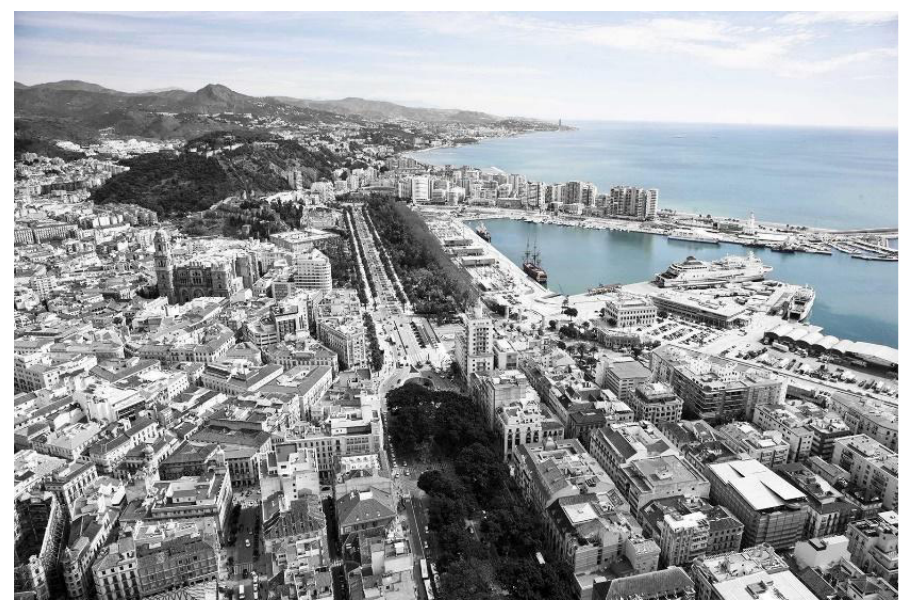

et al., 2010; Pellejero-Martínez, 2005). Lastly, the third period, from the third quarter of the 20th to the present century, has been characterised by the port's modernisation which has seen the development of the container terminal (2004), the cruise ship terminal (2008), and the restoration of the old port docks for the city (2011; Figure 2). The port city has thus managed to shift its offer towards cultural and urban tourism in a clear attempt to differentiate itself from other nearby coastal destinations. Urban improvement plans, the transformation of its waterfront, and the emphasis placed on cruise ship activity have turned Malaga into a point of reference

Figure 2. Images of the port city of Malaga with the huge traffic barrier that separates them. Source: Pedro Marin, edited by María J. Andrade (2012). 
for cruise tourism in the Mediterranean, reaching a flow of 476,970 passengers per year (Malaga Port Authority, 2019 ) in a city with a population of 578,460 inhabitants (Instituto de Estadística y Cartografía de Andalucía, 2020). In the case of Barcelona, the modernisation of the port is carried out with the growth of the port along the industrial coastline, allowing the liberation of Port-Vell and the realisation of a great event such as the 1992 Olympics (Gastaldi \& Camerin, 2018) as the main strategy, like other international cities such as Genoa (Gastaldi \& Camerin, 2020). In Bilbao, the transfer of port activity downstream freed the old port, allowing the construction of the Guggenheim, an iconic building that transformed the image of the city (García Vázquez, 2008; Ponzini \& Akhavan, 2020; Vegara \& de las Rivas, 2004), a strategy followed by many other cities. These three cases of industrial port cities have carried out different dynamics for locating port areas (Costa, 2001) as well as different strategies for relaunching the city, with their own particular impacts on tourism (Andrade \& Costa, 2020; López-Gay et al., 2021).

Nevertheless, the organisation and functioning of the port city has been, and continues to be, the subject of study for experts in many disciplines (Breen \& Rigby, 1994, 1996; Bruttomesso, 1991; Casariego, 1999; Chaline, 1991; Costa et al., 2013; Daamen \& Vries, 2013; Ducruet, 2007; Fleming \& Hayuth, 1994; Gastaldi \& Camerin, 2020; Hall, 1992; Hein, 2011; Hoyle, 2000; Hoyle \& Pinder, 1992; Marshall, 2001; Meyer, 1990), who have focused on highlighting the relationship between the city and its port to describe and understand its configuration from an analysis of its various urban transformations; the functional evolution of the activities they host; the intensity and growth of economic and spatial relationships; the balances between centrality and nodality of the port-city relationship matrix over time; the waterfront adaptation to climate change; along with other issues. In this regard, this article aims to understand how the port invigorates the city of Malaga's urban reality over time.

Undoubtedly, ports are usually places of urban centrality, which is why their constant transformation changes not only their own appearance but also that of the city. As such, the main aim of this article is to study the port-city's organisation and functioning in different periods, the close link between port functions and urban trade, and its historical manifestations on Malaga's urban dynamics. We also analyse the porosity of its borders, the nodes, flows, and urban dynamics that have adapted throughout history to the alterations both the port and the city have undergone. To achieve this, a study is conducted of the city and the port as a single reality, structuring the article around three sections that correspond to the three periods mentioned above (pre-industrial, industrial, and post-industrial periods). Given the importance of the global context when considering the history of a port city, each section describes the global context and then focuses on the case study with graphic contributions and findings derived from each period.

\section{Origin and Evolution of the Port City in the Pre-Industrial Period (8th Century BC-19th Century)}

As Bruttomesso (2010) rightly states, cities have been constructed to establish relationships with the world beyond them. The origin of numerous Mediterranean coastal cities resides precisely in the expansion of trade through the maritime routes across the Mediterranean opened up by the first seafaring peoples (GrindlayMoreno, 2001). This gave rise to the creation of these spaces as central places of urban areas, around which most of their citizens' activity would be carried out (Grindlay-Moreno, 2001). As Morris (2007) affirms, the agora was not just a simple public space but rather an intense concentration of diverse activities.

Malaga has been a port city from its inception and arose from a settlement built around a natural harbour. The city and the port grew together, and port activities were present in the structure and development of urban planning that constantly adapted to the needs of maritime traffic and trade. The origin of the city of Malaga might lie in a small Phoenician port or factory (García Gómez, 1995). The city grew in tandem with the port activity located at two differentiated sites (see Figure 3 ). The existence of two ports led to the appearance of two main forums. On the one hand, the commercial port has been linked to the Plaza, the centre of socio-economic activity. On the other hand, the fish-salting factories and salting pools were located in a second port, which was, therefore, more integrated into the life and activities of its inhabitants and has been associated with the religious centre (Andrade Marqués, 2012). Hence, the presence of these two ports had a crucial influence on the urban development of the city, from its Phoenician roots to the Roman Era and beyond.

\subsection{Muslim Malaga: 8th to 15th Centuries}

When the Arabs settled in the south of the Iberian Peninsula, Malaga played a leading role due to the continued growth of its trading activity through its port. The port was a key element in maritime links, not only with North Africa but also with a wide variety of ports in the Mediterranean, the Far East, and Northern Europe (Rodríguez Alemán, 1984). During the Muslim era, from approximately the 8 th to the 15 th centuries, the existence of two ports was maintained, though not exactly in the same location. The more commercial port remained next to the river, though somewhat further out into the sea due to constant silting. It was delimited by the shipyards and the Castle of the Genovese, which served as a hinge to the urban port (Figure 4). This second port was located in the central bay and economic activity was concentrated in the surroundings of the Castle of the Genovese, the most important centre of the port-city 


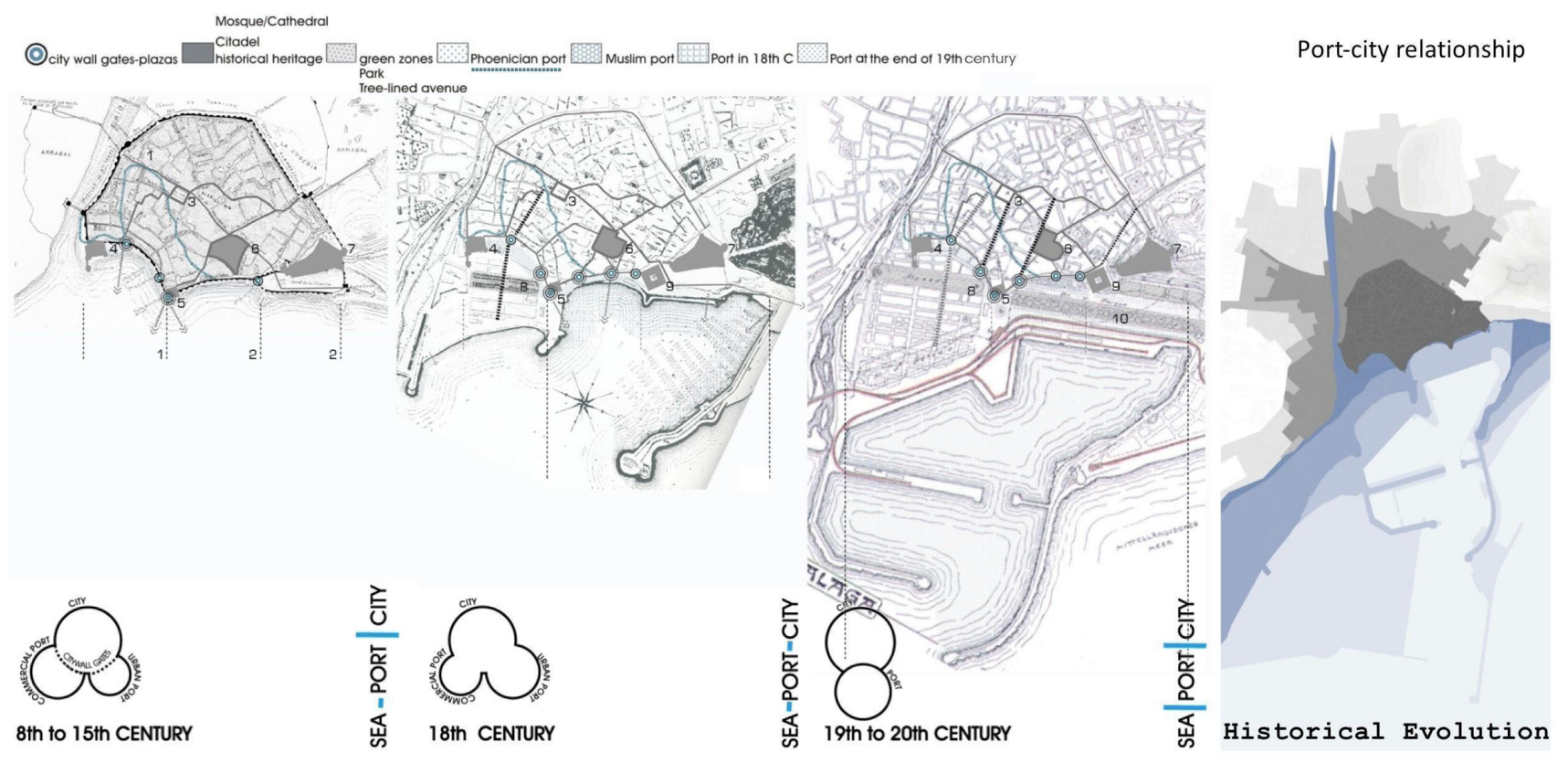

Figure 3. Historical evolution of the port-city relationship of Malaga: Muslim Malaga, 8th to 15th centuries; 18th century, demolition of the ramparts; 19th century, Industrialisation. Notes: 1. Commercial Port; 2. Urban Port; 3 . Plaza de la Constitución; 4. Shipyards (currently the market); 5. Castle of the Genovese (currently the Plaza de la Marina); 6. Mosque/Cathedral; 7. Fortress/Arab Citadel; 8. Alameda; 9. Customs House (currently the Museum); 10. Park. Source: María J. Andrade (2012).

relationship. The urban reflection of these port activities inside the medina was to be found in the Plaza, which maintained its character as a forum.

The layout of the city is perfectly defined with the Arabs, with such force that subsequent centuries would be unable to erase that layout. Its shape reflects the relations between basic territorial arteries and the important Granada-Africa route since the Port of Malaga was the Kingdom of Granada's main port. The city's economic and religious hubs, like the Plaza and the Mosque, were established at the crossroads of these arteries, with all the city's activities taking place at the gates of these arteries (Figure 4): "Malaga was a great import-export centre capable of creating an entire communications system, to which the city itself was subordinated" (Rodríguez Alemán, 1984, p. 23). Despite the existence of the ramparts as a boundary, the port-city relationship was highly intense and practically all the city's activities took place at the gates which opened up to the sea. In this way, porosity occurs because the existence of the edge itself is questioned. Despite the barrier posed by the rampart, there is a physical porosity marked by the rampart gates and their connections with the two forums of the city (functional porosity), causing urban flows and dynamics around them (social porosity).

Malaga was conquered by the Catholic Monarchs in 1487, sparking changes in its urban structure. Nonetheless, the city continued to maintain its threepole functionality: a religious centre (the Cathedral), a civic centre (the Plaza), and a mercantile centre (the Port), which still had two different port locations. Each port was linked to an internal forum, the Plaza and the Cathedral, thus creating the city's layout of streets and areas of activity. Such is the case of Calle Nueva, which was created to link the port (Sea Gate) to the Plaza, thus transferring commercial activity from the old Alcaicería, or goods market, to this street.

\subsection{The 18th Century: Demolition of the Ramparts}

The 18th century was a positive era for Malaga. It can be construed as the century of reforms, which began after the War of the Spanish Succession in the reign of Phillip V. Malaga formed part of the important demographic boom that took place across Europe during the 18th century. This had a direct impact on local urban planning since new facilities were required, thus producing a further expansion of the city. As Vilar (1962) suggests, not all cities and regions underwent this change to the same extent. It was essentially the maritime cities at the periphery which consolidated a bourgeoisie that was mainly dedicated to trading and manufacturing, especially in the second half of the century. The rise in economic activities required an increase in transport infrastructures, which led to an improvement in the road network and the facilities of some ports to channel foreign trade through them (Rodríguez Alemán, 1984).

The end of the 18th century and the beginning of the 19 th century was an era marked by prosperity in Malaga. This was reflected in a series of significant actions that would change the relationship of three realities, the city, the port, and the sea, and lead to the culmination of this 

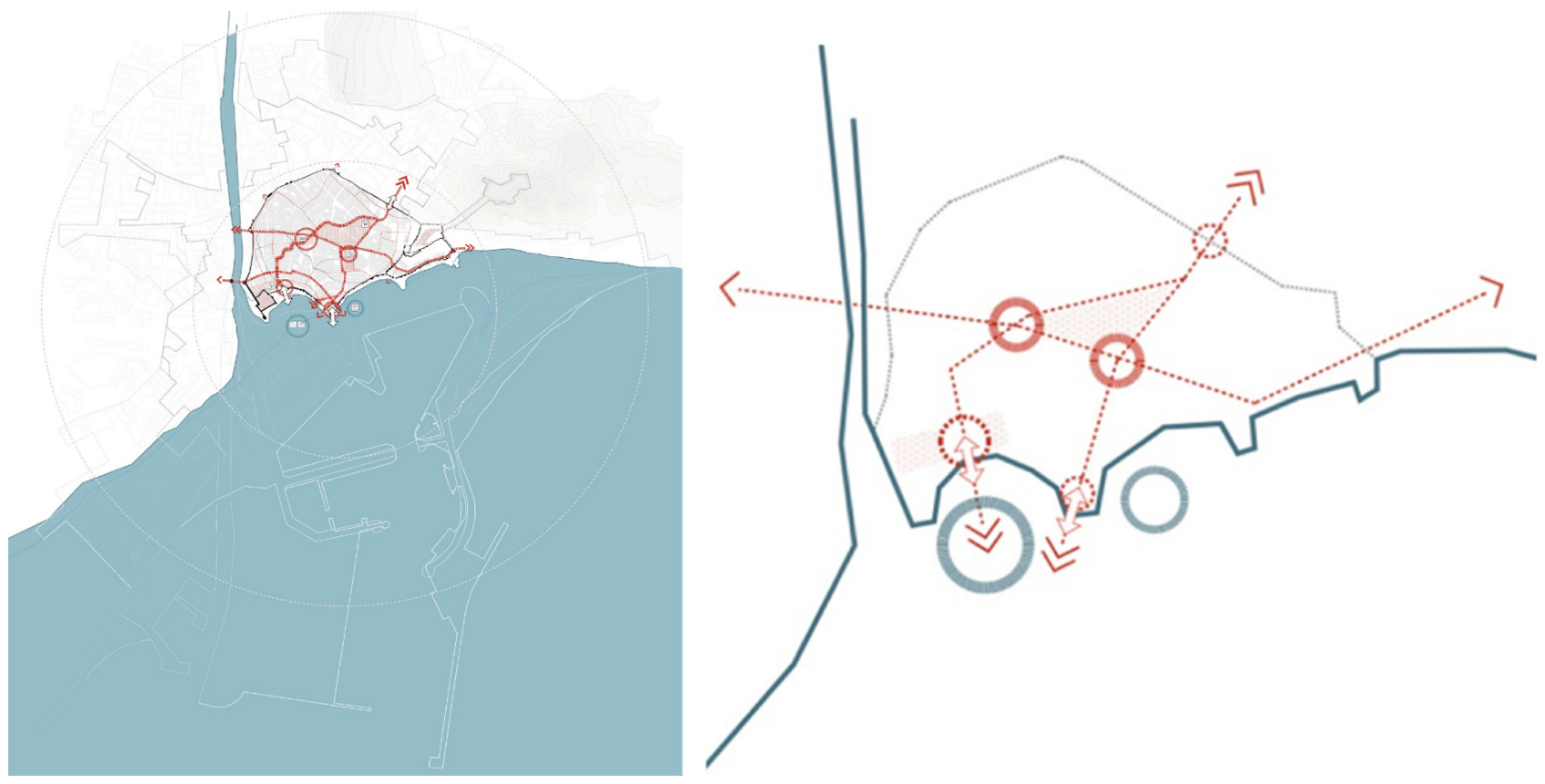

Figure 4. Analysis of the port city of Malaga's configuration: Physical, functional, and social porosity; Two ports-two forums-land and maritime connections (Muslim era). Source: María J. Andrade (2012).

relationship. The first important event was the demolition of the medieval ramparts in 1786 , which had separated the port from the city for ten centuries. The city and the sea were thus joined by an open port, and the dock's edge was turned into just another city street. The construction of the Eastern Dock (Muelle de Levante) along with the new Customs House led to the definitive transfer of most of the port's activity to this site. This freed up a large part of the coastline and allowed for the creation of the Alameda, the city's main leisure area (García Gómez, 1995). The Alameda and the dock made up the city's waterfront, which had been turned into a continuous promenade next to the sea. For its part, the area around the Castle of the Genovese, located between the Western Dock and the Espartería Gate (Puerta de Espartería), would now be the nexus between the port and the city. The Sea Gate (Puerta del Mar) maintained its importance from a mercantile perspective. It was then that the city expressed the importance of the communication that would be opened up between the population of the seashore and the rest of the city (Figure 5). This would be the time of greatest porosity, without boundaries between the port and the city and with a huge urban waterfront and a green space, which connects the port and the city as a whole.

\section{The Role of Industrialisation in the Port-City Relationship (19th-20th Century)}

The demolition of the defensive ramparts in the 19th century, which can be considered a common phenomenon in almost all European cities, created a physical continuity between the port and the city. However, this continuity would soon be eradicated by another kind of wall, an industrial wall. The port-city relationship became increasingly distant as a result of the industrial revolution, which, despite being a great economic boost for the port and the city, brought with it a rupture of said spatial continuity. From then onwards, the port area was seen as an entity that was disconnected from the city's historical shape, although it coexisted with the city both physically and socially (Casariego, 1999). The development and progress of these cities in the new industrial era were reflected in their port frontages.

The transformation of ports in the industrial period was characterised above all by the appearance of steam, which transformed navigation and the techniques for carrying out public works (Alemany Llovera, 1991). Ports were thus modernised, harbour mouths made narrower by lengthening breakwaters, and dock alignments extended, in many cases to gain greater water depth through filling works that had a repercussion on the morphology and layout of cities. The rise and development of railways and their introduction into port areas also revolutionised exchange capacity and sea transport. The impact of these changes is evident in the structure and functioning of cities (Alemany Llovera, 2010). The vacant spaces freed up by the demolition of ramparts were generally taken advantage of for port activities, railway lines that crossed these cities along their waterfronts and even for roadways that would be the origin of future barriers between the port and the city.

The transformation of ports in the industrial period, therefore, had a direct impact on the configuration of the city. This ended up creating both a barrier between the city and the sea, as well as social segmentation along the coastline (Alemany, 1999, 2010). The industrial city containing factories and workers' settlements was devel- 


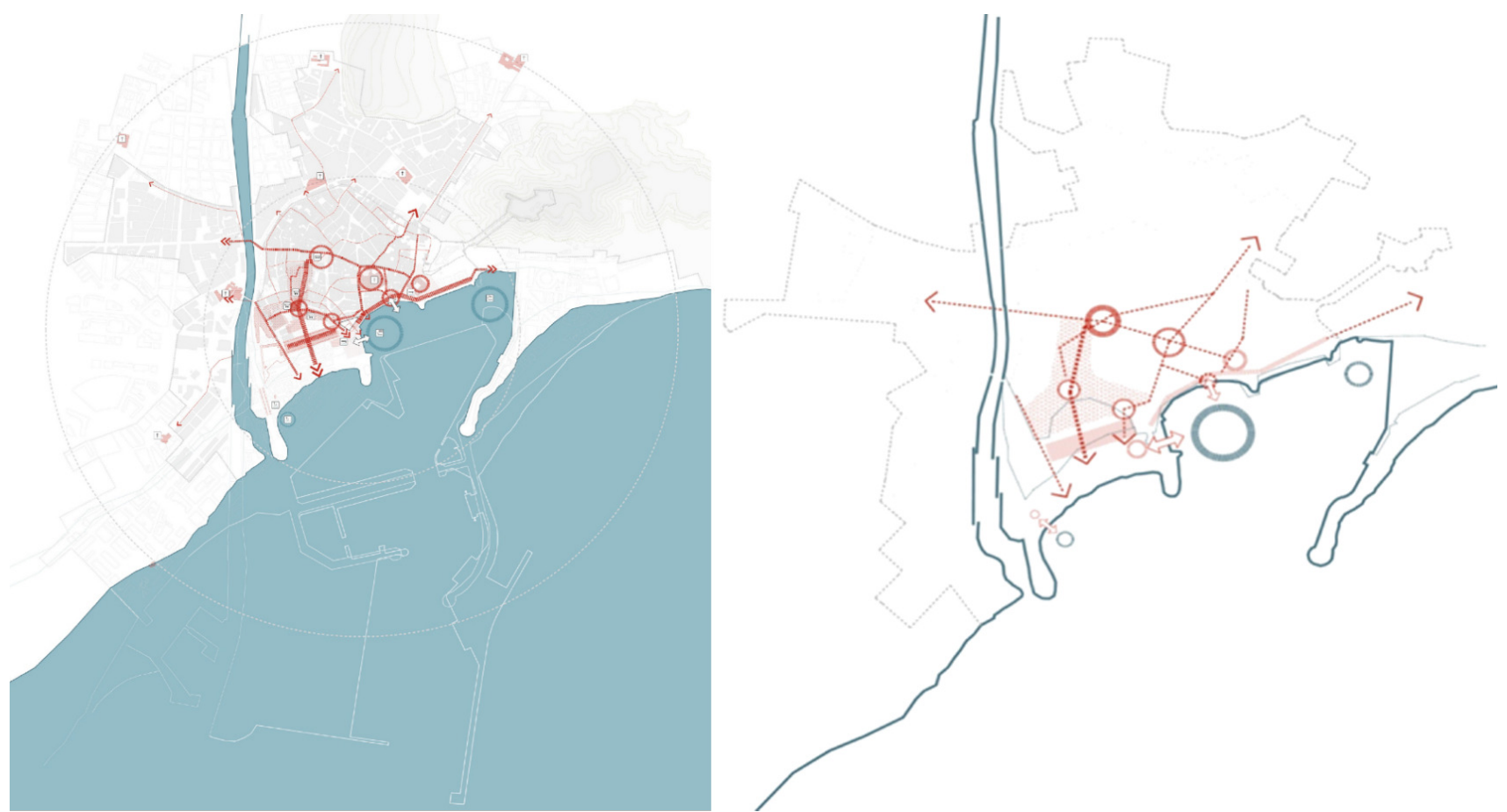

Figure 5. Study of the port city of Malaga's configuration in the 18th century: Physical, functional, and social porosity; Demolition of the ramparts, upon whose imprint a seaside promenade was built. Source: María J. Andrade (2012).

oped on one side of the port, while a spa city containing the bourgeoisie's second homes was found on the other (Reinoso Bellido, 2005).

This social segregation of the coastline around the port was visible in cities like Santander, Barcelona, or Malaga, which underwent extensive development during the industrial period. Malaga's industrial bourgeoisie built high-rise tower blocks on the city's outskirts, promoted factories and workshops, attracted foreign talent, and fostered railways and port improvements. Subsequently, the economic slowdown of the 1950s saw Malaga endeavour to overcome the slowdown by enhancing the port and building railways, although by then industry had already lost its regional weight.

One of the greatest urban contributions of the period was Calle Larios. This street was built to link the Plaza with the port's main gate, the Espartería Gate, a particularly important site due to its location on the Alameda, and which thereby concentrated a great deal of activity. As the city's main shopping artery, the layout of Calle Larios mimics the model set by Calle Nueva, which in the past linked the Plaza to the port's main gate. Both thoroughfares have shaped the city's shopping district since then and continue to do so to this day.

The modernisation of the port, along with the regularisation of its docks on land reclaimed from the sea, allowed for the city's growth. As such, the park-the city's main green area-and the new residential area, the Heredia Enlargement (Ensanche Heredia), were both promoted, but at the same time, the borders between the port facilities and the city were precisely set by means of a fence that prevented any physical or visual contact with the sea. The port was not only present in the city's growth to the west with factories and their settlements, but this growth also allowed the port to expand to the east thanks to the railway line, which was subsequently converted into a seaside promenade serving as a central leisure and relaxation area. Hence, while the port spurred industrial manufacturing development along the western coastline, it likewise fostered an incipient tourist industry in the east. Despite the distancing of the port from the city, it is clear that the urban developments of the 19th and 20th centuries were once again closely linked to the port, not only with regards to the opening up of connections to the city and development of the waterfront but also to the widening and development of the eastern and western coastlines. The port was once again the major factor in the city's development (Figure 6). However, as the port becomes a port area, an independent entity, in addition to the barriers posed by railroad tracks and fences, governance and land ownership become real boundaries that hinder the porosity between the port and the city even to this day. This time will be the one with the greatest physical and functional discontinuity between the port and the city.

\section{The Transformation of the Port-City Relationship in the Post-Industrial Period (Late 20th Century-Present)}

The third quarter of the 20th century was marked by significant port growth. The container traffic phenomenon, which is associated with logistics management, the changes in energy use and shipping routes and networks, are the origin of new facilities being relocated far 


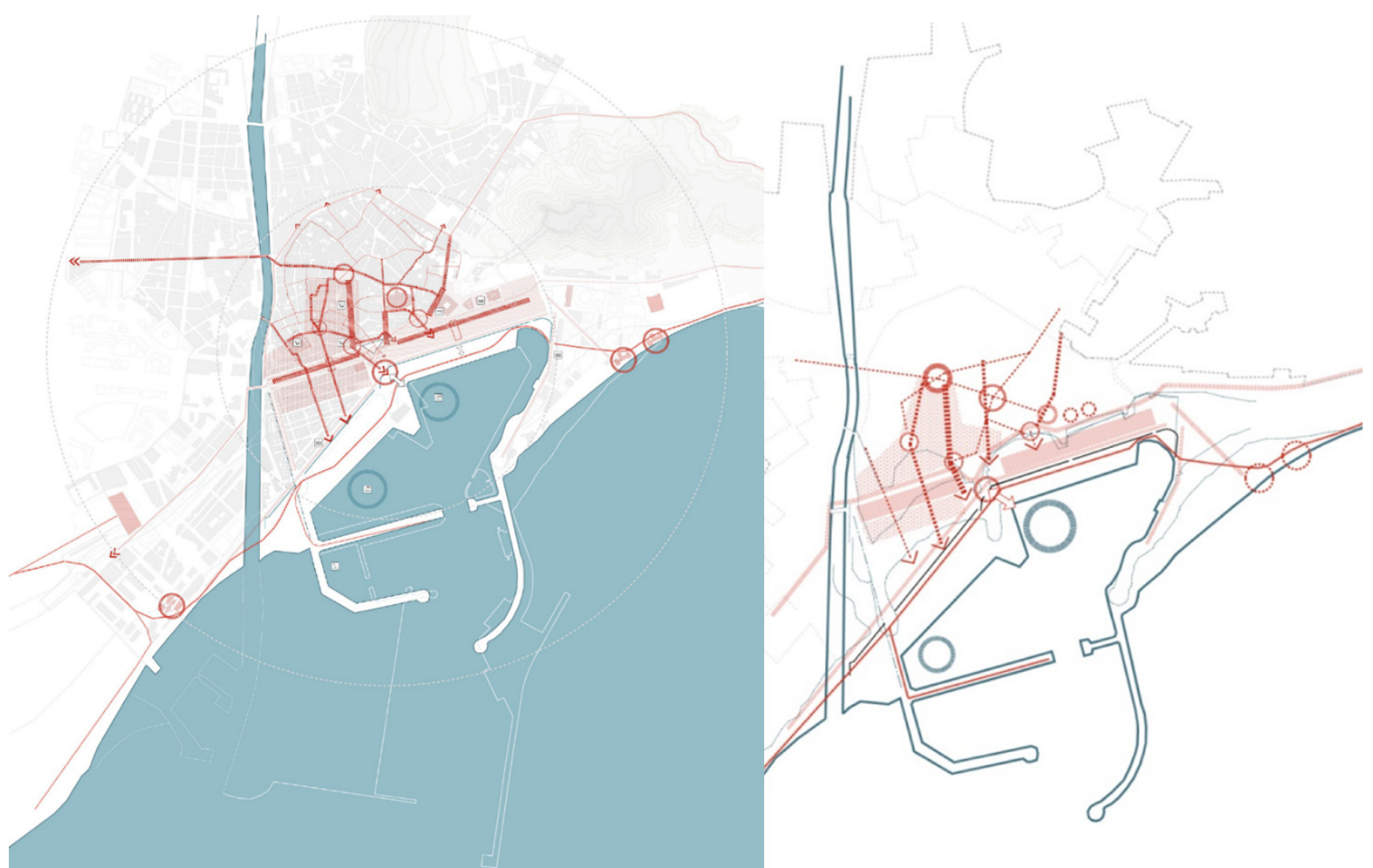

Figure 6. Study of the port city of Malaga's configuration around different physical, functional, and social factors (19th century): The port closes in on itself, separated from the city by fencing, roads, and railway lines, and from the sea by the narrowing of the harbour mouth. Source: María J. Andrade (2012).

from the old port areas (Baudouin \& Collin, 1994; Hoyle, 1996; Hoyle \& Pinder, 1981; Malone, 1996; Mosso, 1996). The resulting deindustrialised spaces were used as places of opportunity to recover historic city centres that were in decline at the time. This gave rise to the waterfront phenomenon, which became an essential paradigm for post-industrial cities (Bruttomesso, 2001). The academic literature on waterfronts is abundant (Breen \& Rigby, 1994, 1996; Bruttomesso, 1991; Carpenter et al., 2018; Hein, 2011; Marshall, 2001; Meyer, 1990, 1999), as is the literature on their classification (Andrade Marqués, 2012; Brownill, 2013; Perea-Medina et al., 2018; Schubert, 2011; Shaw, 2001) ranging from the first American waterfront experiences focused on leisure and shopping, to the ones which take on the role of tourist ports (McCarthy, 2003; Perea-Medina et al., 2018). In a period that seeks to maintain port activities that are compatible with urban life, the cruise industry stands out as one such activity, straddling as it does both tourism and port activities (Capocaccia, 2001). If there has been an effort to get inhabitants closer to their port throughout the different stages of the waterfront phenomenon, this objective is currently in disarray as thousands of tourists make their way along the waterfront to historic city centres daily (Perea-Medina et al., 2018).

Malaga is no exception to this rule. The need for port improvements and the rush to find new areas that could rescue its historic city centre led to a contentious process to plan this space. This process began in 1985 and would last for over 20 years. In the face of the endless negotiations on the port-city interface, both the port and the city continued to move forward and develop as independent spaces. The port grew seaward (Figure 7), freeing up some of the docks near the historic city (Docks 1 and 2), while maintaining port activity at others (Docks 3 and 4, passengers, and ro-ro). When a development agreement was reached on Docks 1 and 2 in 2010, the city centre had already been renovated, the container terminal was in operation (2004) and the eastern breakwater was beginning to receive the first cruise ships (2008; Andrade Marqués, 2012). Despite this, the port-city analysis conducted by Andrade Marqués et al. (2012) placed Malaga within the international context of waterfronts, positively highlighting the quality of its public spaces to deal with the powerful combination of leisure and entertainment which characterises the city. These docks have been mixing uses-urban docks 1 and 2 maintain port activity as a terminal for luxury cruise ships, mega-yachts, boats for sports, and tourist use-and enriching the cultural offering over time with museums like the Pompidou Centre or craft shops and local products. Maintaining port activity so close to the city (both urban docks 1 and 2 and docks 3-9: passengers, cruisers, ro-ro, fishing, containers, and bulk) reinforces its identity and turns 


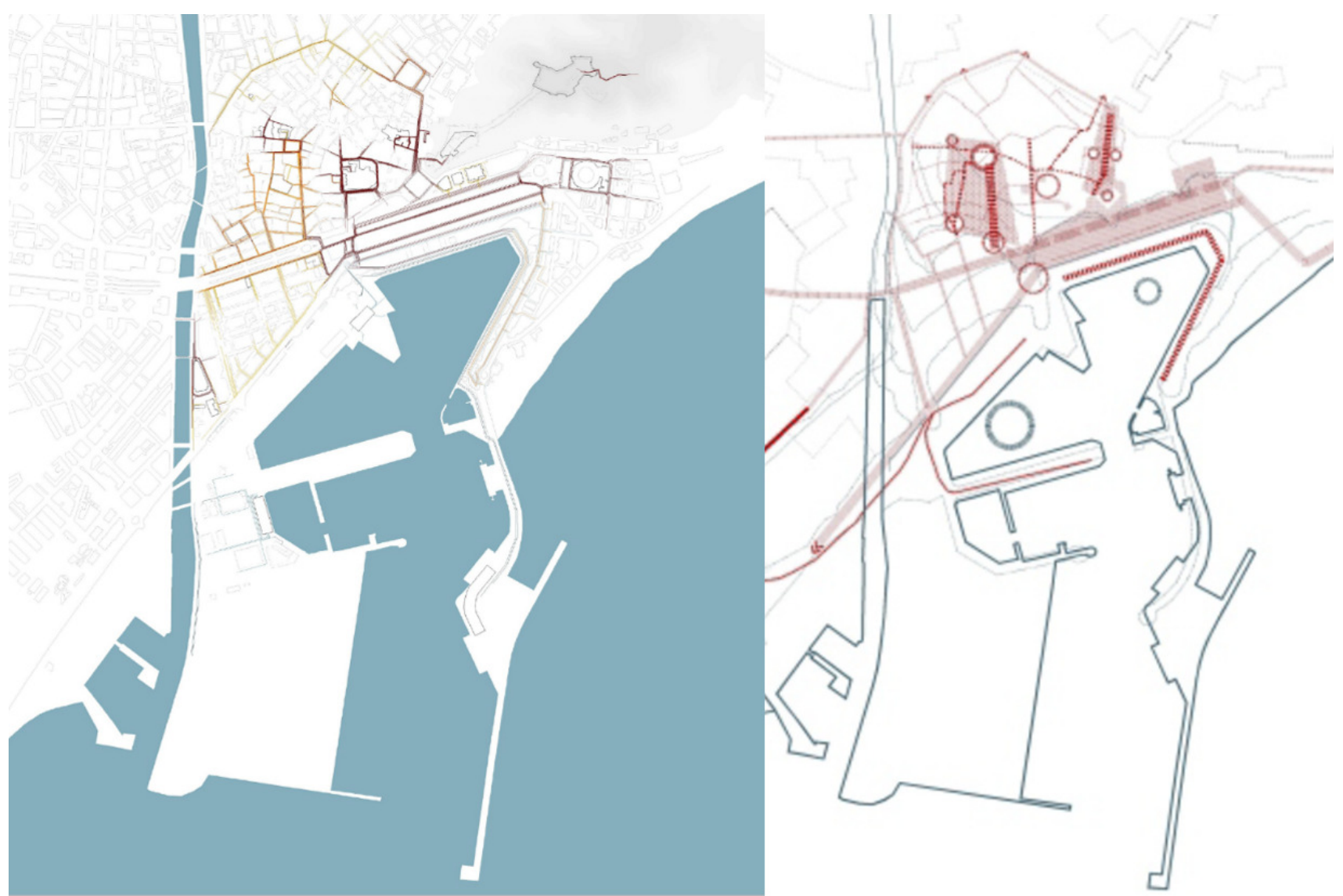

Figure 7. Study of the port city of Malaga's configuration around different physical, functional, and social factors (21st century). Source: María J. Andrade (2012).

Malaga into a highly attractive tourist destination given the cruise terminal's proximity to the renovated historic city centre and a broad cultural offering. Despite physical barriers (Andrade et al., 2020), the governance structure (Daamen \& Vries, 2013) and International Ship and Port Facility Security Code, the porosity between the port and the city is a reality not only through the punctual connection between both-which should be improvedbut also through the visual relationship with the ships, cranes, and port activity that reinforce the identity of the port city.

The historic city centre is still functionally organised around the same two historic forums: the Plaza de la Constitución on the one hand, which still maintains its commercial nature, and the Cathedral on the other, which acquired this role due to its historical importance, although it still maintains its religious function. Both forums have expanded along linear nodes, the cultural artery is Calle Alcazabilla as a prolongation of the Cathedral, and the commercial artery is Calle Larios as an extension of the Plaza de la Constitución. The latter artery divides the historic city centre into two 'cities.' A more active, community-based city, where most neighbourhood amenities are concentrated, is on one side, and a more touristic and contemplative city containing more museums and monuments is on the other (Andrade Marqués, 2012). At the same time, the trans- formation of Docks 1 and 2 in the urban port, together with the fact that the port continues to operate in the old city centre, ensure that two ports, which are physically and functionally distinct, coexist in the very heart of the historic city centre of Malaga, as has always been the case throughout history. Each of these ports-one an urban port and the other a commercial port-is linked to one of the two parts of the historic city centre. In other words, the operational port is adjacent to the active city, while the urban and cruise ship port is linked to the more contemplative part of the city. Despite this, and after more than 20 years of urban planning focused on the port-city relationship and ten years of the waterfront redevelopment project's existence, the same historical borders remain to this day, such as the ramparts transformed into 19th century barriers, which were then converted into more than eleven traffic roadways that separate the port from the city (for the analysis of the waterfront see Andrade et al., 2020).

The cruise industry has undoubtedly been one of the most dynamic and fastest-growing sub-sectors of tourism over the last decade (Sun et al., 2011), especially in the Mediterranean basin, where cities offer a wide variety of assets that are easily accessible and attractive for historical and cultural tourism (Castillo-Manzano et al., 2014; Gui \& Paolo Russoz, 2011; Rodrigue \& Notteboom, 2013; Soriani et al., 2009). Such growth has 
led to the beginning of Malaga's touristification, and, although this is not as intense as in the cases of Barcelona or Venice, it has triggered a focus on economic activity and urban planning geared at tourism. This has brought with it a rise in the number of museums, hotels and rental apartments, followed by the historic city centre's gentrification, whereby local inhabitants are forced to abandon the city centre, coupled with the trend to replace local activities with international global companies dedicated to commerce and restoration (Andrade et al., 2020). This search for a global image leads most of those in power to view the future in terms of skyscrapers and the city's growth in terms of its expansion, as opposed to more sustainable proposals advocating for the conservation and reuse of the industrial and port heritage, which would increase the current port-city border's porosity.

\section{Conclusions}

This brief view over time allows us to show how port-city porosity has been a determining factor in Malaga's development and how it continues to be so concerning the challenges broached today with a view to the future.

One of the most important elements required to understand this city, its morphology and how it functions, is that the city has been built around two ports. The urban reflection of these two ports is to be found in the two main forums which have been preserved throughout history and around which the city is organised (Plaza and Temple). By studying how the city functions around these two forums and the links each of them has to its port, the layout of its streets, the activities which take place at each site, etc., the way the city is assembled can be viewed as a perfect mechanism. This powerful structuring of the city has survived to this day. Although the port's modernisation during the period of industrialisation resulted in both ports merging into a single autonomous and independent structure, those two ports can still be perceived. The two forums still maintain their nodal role in the way the city functions, with one being more commercial and active, while the other is more contemplative and cultural, each in keeping with the rhythm of its distant port.

Despite its borders, the city of Malaga has always faced the sea and its relationship with its port has created very diverse situations (Figure 8). However, even in historical periods when defensive systems made it difficult, these relationships have always sought porosity and openness to the port and the sea. The rampart gates which once faced the sea, the crowded squares and the subsequent promenades built along the port's waterfront at different stages were all places that linked the port directly to the city. These are the spaces the city's inhabitants have most visited and admired, finding in them a changing dynamic landscape where people, wealth, culture and merchandise travelled back and forth from distant lands. Unfortunately, the defensive borders built during the Muslim era still survive today, transformed into barriers comprised of up to eleven traffic roadways. This discontinuity among the historic city, the actions undertaken in the 19th century, and today's interventions have been shifted on to an operational framework since the city lacks a common urban planning scheme to resolve the different projects' links and coordination through an overarching view.

As has been demonstrated, a historical reading allows one to comprehend the reality of the port city in: (i) its physical scope through the communications arteries which define the city; (ii) its functional scope corresponding to the forums around which the city is organised and; and (iii) its social scope through urban dynamics. Nonetheless, this view on the border and flows in the complex port-city relationship also opens up opportunities for Malaga's present and future by weighing opportunities and risks in a world where territorial decisions are increasingly double-edged. Just as they have been in the past, port docks today are the door to the city for cruise tourism flows. However, the negative impacts caused by the touristification process need to be addressed. The industrial waterfront and its heritage are attractions for collective life alongside the water, but their responsible renovation and social utility must also be considered. The densely urbanised historic city centre benefits from the former port area's open spaces, though large infrastructure barriers still divide both spaces. Lastly, if the port city forms part of Malaga's collective memory, a new memory for the future should be built.

Port-city porosity is today a multifaceted and complex topic, in which several perspectives overlap and oblige to construct integrated overviews. As can be seen throughout history, it involves an effort to break barriers (Costa, 2007b) and to seek new balances in keeping with strategic views of the future. But not all the broken barriers are the same, and new research on the contemporary dynamics is needed. Social porosity presents a double perspective when the port territories are opened to the city: as the democratisation of the access to the waterfront brings new opportunities for urban and port development in domains such as public space, leisure, culture and tourism; negative impacts might occur, as segregation finds its expression in phenomena such as the touristification and the gentrification of the surrounding urban areas. The same happens with the functional porosity in the rediscovering of the waterfront areas. On one hand, the functional permeability allows for the location of public facilities and other uses that did not have space to be located in the dense historical city, both in new buildings and the reuse of industrial heritage. On the other hand, port-cities must be addressed the danger of transforming these new waterfronts on thematic parks for leisure and tourism. And the same also occurs in the physical porosity, as the classical conflict between the waterfront longitudinal barriers (walls, structural avenues, train) and the transversal integration of urban tissues continues to be a difficult equation on the regeneration of port-cities. As observed, in 


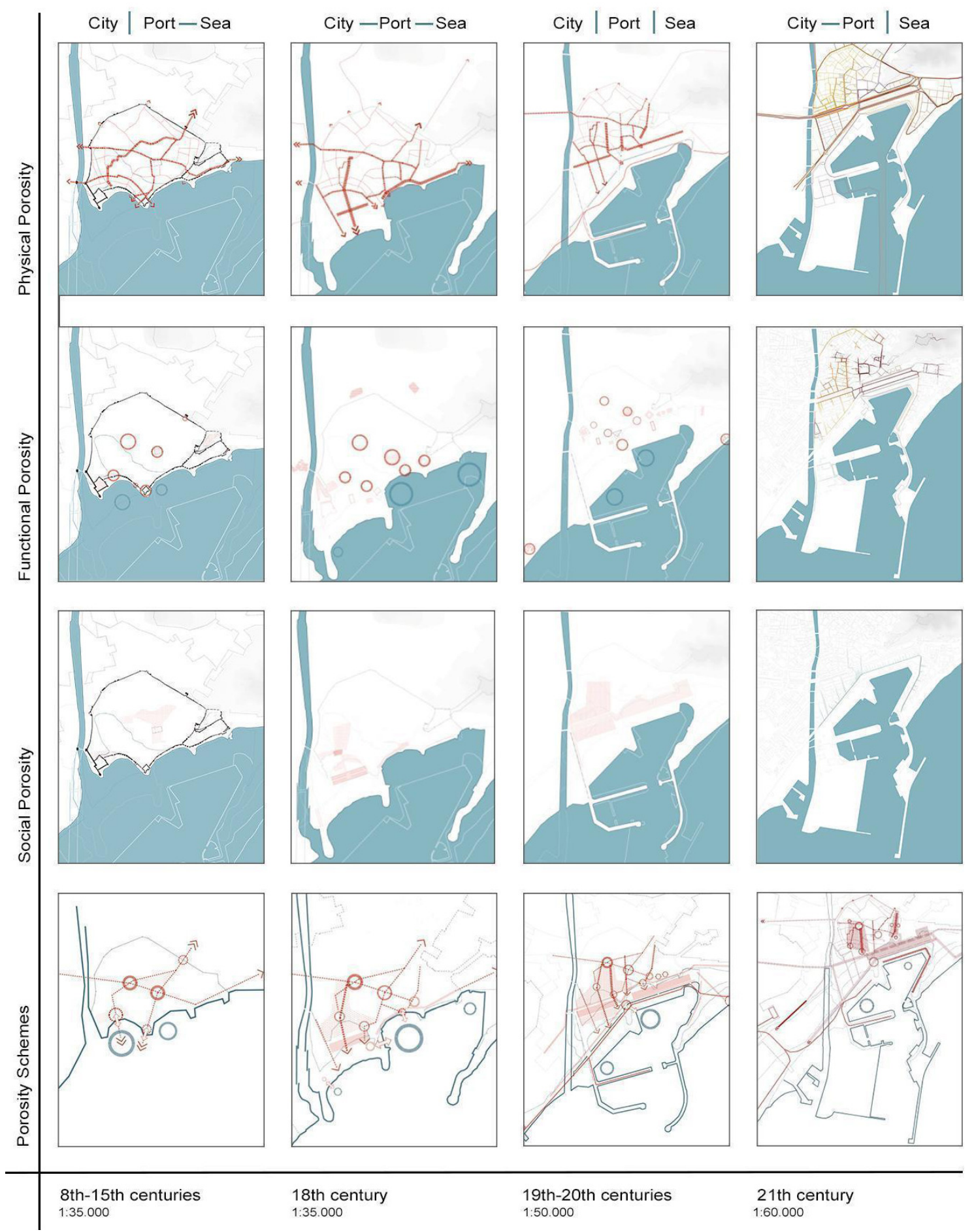

Figure 8. Joint reading of the port and the city throughout history; Physical, functional, and social analysis. Source: María J. Andrade (2012).

Malaga, as well as in several other port-cities, this interface remains a contemporary space of opportunity, a challenge for the city, the port, and the citizens.

\section{Acknowledgments}

We are grateful for the excellent feedback provided by the anonymous reviewers.

\section{Conflict of Interests}

The authors declare no conflict of interests.

\section{References}

Alemany Llovera, J. (1991). Los puertos españoles en el siglo XIX [Spanish ports in the 19th century]. Ministerio de Obras Públicas y Urbanismo. 
Alemany Llovera, J. (2010). La transformación de los puertos desde la revolución industrial [The transformation of ports since industrial revolution] Portus, 19 (May), 16-17.

Andrade, M. J., \& Costa, J. P. (2020). Touristification of European port-cities: Impacts on local populations and cultural heritage. In A. Carpenter \& R. Lozano (Eds.), European port cities in transition: Strategies for sustainability (pp. 187-204). Springer.

Andrade, M. J., Costa, J. P., \& López, J. B. (2020). 3DPortCityMeasure: Methodology for the comparative study of good practices in port-city integration. Sustainability, 12(3). https://doi.org/10.3390/su12030880

Andrade Marqués, M. J. (2012). The transformations of the Port of Malaga in the discussion of the Waterfronts. University of Malaga.

Andrade Marqués, M. J., Blasco López, J., \& Marín Cots, P. (2012). Puerto-ciudad. Estudio comparativo de buenas prácticas [Port-city. Comparative study of good practices]. Servicio de Programas Europeos del Ayuntamiento de Málaga, Observatorio de Medio Ambiente Urbano OMAU.

Barke, M., Mowl, G., \& Shields, G. (2010). Málaga: A failed resort of the early twentieth century? Journal of Tourism History, 2(3), 187-212. https://doi.org/ 10.1080/1755182X.2010.523145

Baudouin, T., \& Collin, M. (1994). Culture des villes portuaires et mondialisation de l'economie [Culture of port cities and the globalization of the economy]. Laboratoire d'Histoire Maritime, Université de Paris Sorbonne, AIVP.

Benjamin, W. (1985). Naples. In W. Benjamin (Ed.), In one way street and other writings (pp. 167-176). Verso Books.

Bird, J. (1963). The major seaports of the United Kingdom. Hutchinson University Library.

Braudel, F. (1980). El Mediterráneo y el mundo mediterráneo en la época de Felipe II [The Mediterranean and the Mediterranean world in the time of Philip II] (2nd ed.). Fondo de Cultura Económica.

Breen, A., \& Rigby, D. (1994). Waterfronts cities reclaim their edge. McGraw-Hill.

Breen, A., \& Rigby, D. (1996). The new waterfront: A worldwide urban success story. Thames and Hudson.

Brownill, S. (2013). Just add water: Waterfront regeneration as a global phenomenon. In M. E. Leary \& J. McCarthy (Eds.), The Routledge companion to urban regeneration (pp. 45-55). Routledge. https:// www.routledgehandbooks.com/doi/10.4324/97802 03108581.ch3

Bruttomesso, R. (Ed.). (1991). Waterfront: Una nueva frontiera urbana, 30 progetti di riorganizzazione $e$ riuso di aree urbane del sul fonte d'acqua [Waterfront: A new urban frontier, 30 projects of reorganization and reuse of urban areas on the water source]. International Centre Cities on Water.

Bruttomesso, R. (2001). Complexity on the urban waterfronts. In R. Marshall (Ed.), Waterfronts in post- industrial cities (pp. 39-49). Spon Press.

Bruttomesso, R. (2010). Para una historia de la ciudad portuaria. Desde los orígenes hasta la era industrial [For a history of the port-city. From the origins to the industrial age]. Portus, 19, 8-13.

Capocaccia, F. (2001). Cruising in the Mediterranean. Portus, 2, 14-19.

Carpenter, A., Lozano, R., Sammalisto, K., \& Astner, L. (2018). Securing a port's future through circular economy: Experiences from the Port of Gävle in contributing to sustainability. Marine Pollution Bulletin, 128, 539-547. https://doi.org/10.1016/j.marpolbul.2018. 01.065

Casariego, J. (1999). Waterfronts de nuevo: Transformaciones en los frentes urbanos de agua [Waterfronts again: Transformations in urban waterfronts]. Ayuntamiento de Las Palmas de Gran Canaria.

Castillo-Manzano, J. I., Fageda, X., \& Gonzalez-Laxe, F. (2014). An analysis of the determinants of cruise traffic: An empirical application to the Spanish port system. Transportation Research Part E: Logistics and Transportation Review, 66, 115-125. https://doi.org/ 10.1016/j.tre.2014.03.008

Chaline, C. (1991). Les nouveaux fronts d'eau: Une unique opportunité urbaine [New waterfronts: A unique urban opportunity]. Villes Ports, 7, 2-5.

Costa, J. P. (2001). Harbour zones spatial dynamics and perspectives of land release to urban renewal. Monografies Socio-Ambientales, 30, 48-63.

Costa, J. P. (2007a). La ribera entre proyectos: Formación y transformación del territorio portuario, a partir del caso de Lisboa [The riverbank between projects: Formation and transformation of the port territory, from the case of Lisbon]. Universitat Politècnica de Catalunya.

Costa, J. P. (2007b). City, port and infrastructure: Breaking the barriers to integrated waterfront regeneration. NovaTerra, 7(1), 1-25.

Costa, J. P., Matos Silva, M., \& Nouri, A. (2013). Climate change adaptation and urbanism: $A$ developing agenda for Lisbon within the XXI Century. Urban Design International, 19(1), 77-91. https://doi.org/ 10.1057/udi.2013.15

Daamen, T., \& Vries, I. (2013). Governing the European port-city interface: Institutional impacts on spatial projects between city and port. Journal of Transport Geography, 27, 4-13.

Ducruet, C. (2007). A metageography of port-city relationships. Edited by J. Wang, D. Olivier, T. Notteboom, \& B. Slack. Ports, cities, and global supply chains (pp. 157-172). Routledge. https://halshs.archivesouvertes.fr/halshs-00458067

Ducruet, C., \& Lee, S. W. (2006). Frontline soldiers of globalisation: Port-city evolution and regional competition. GeoJournal, 67(2), 107-122. https://doi.org/ 10.1007/s10708-006-9037-9

Fleming, D. K., \& Hayuth, Y. (1994). Spatial characteristics of transportation hubs: Centrality and interme- 
diacy. Journal of Transport Geography, 2(1), 3-18. https://doi.org/10.1016/0966-6923(94)90030-2

García Gómez, F. (1995). Los orígenes del urbanismo moderno en Málaga: El paseo de la Alameda [The origins of modern urbanism in Malaga: Paseo de la Alameda]. Universidad de Málaga.

García Vázquez, C. (2008). Ciudad Hojaldre. Visiones urbanas del s. XXI [Puff pastry city. Urban visions of the 21st century]. Gustavo Gili.

Gastaldi, F., \& Camerin, F. (2018). Transformaciones urbanas y grandes eventos en Italia y España a partir de 1992 [Urban transformations and major events in Italy and Spain from 1992]. Ciudad y Territorio: Estudios territoriales, 50(196), 201-216.

Gastaldi, F., \& Camerin, F. (2020). Renzo Piano's projects for the waterfront of Genoa: 1981-2017. Territorio, 93, 147-155.

Grindlay Moreno, A. L. (2017). Ciudades y puertos [Cities and ports]. Ciudades, 11(11), 53-80. https://doi.org/ 10.24197/ciudades.11.2008.53-80

Grindlay-Moreno, A. L. (2001). Los puertos Mediterráneos Andaluces: Centralidad urbana y dimensión territorial [Andalusian Mediterranean ports: Urban centrality and territorial dimension]. Departamento de Expresión Gráfica, Arquitectónica y en Ingeniería, Universidad de Granada.

Guardia, F. M., Monclús, J., \& Oyón, J. L. (1996). Los atlas de ciudades entre la descripción y la comparación. El Atlas Histórico de Ciudades Europeas [The atlases of cities between description and comparison. The historical atlas of European cities]. Ayer, 23, 109-134. https://www.jstor.org/stable/41324680

Gui, L., \& Paolo Russo, A. (2011). Cruise ports: A strategic nexus between regions and global lines-evidence from the Mediterranean. Maritime Policy and Management, 38(2), 129-150. https://doi.org/10.1080/ 03088839.2011 .556678

Hall, P. (1992). Waterfronts: A new urban frontier. Aquapolis, 1(1), 6-17.

Harvey, D. (1973). Social justice and the city. University of Georgia Press.

Hein, C. (Ed.). (2011). Port cities: Dynamic landscapes and global networks. Routledge.

Hein, C., \& van Mil, Y. (2020). Mapping as gap-finder: Geddes, Tyrwhitt, and the comparative spatial analysis of port city regions. Urban Planning, 5(2), 152-166. https://doi.org/10.17645/up.v5i2.2803

Hoyle, B. (2000). Global and local change on the port-city waterfront. Geographical Review, 90(3), 395-417.

Hoyle, B. S. (1996). Cityports, coastal zones and regional change: International perspectives on planning and management. Wiley.

Hoyle, B., \& Pinder, D. (Eds.). (1992). European port cities in transition: Strategies for sustainability. Belhaven Press.

Hoyle, B. S., \& Pinder, D. (Eds.). (1981). Cityport industrialization and regional development: Spatial analysis and planning strategies. Pergamon Press.
Instituto de Estadística y Cartografía de Andalucía. (2020). Información estadística relevante para la política municipal de vivienda. Málaga [Relevant statistical information for municipal housing policy. Malaga].

Kwak, N. H. (2017). Interdisciplinarity in planning history. In C. Hein (Ed.), The Routledge handbook of planning history (pp. 25-35). Routledge.

Landa, I. (2020). Una aproximación a la historiografía urbana: Algunos aspectos epistemológicos y metodológicos [An approach to urban historiography: Some epistemological and methodological aspects]. EURE (Santiago), 46(139), 259-276. https:// doi.org/10.4067/S0250-71612020000300259

López-Gay, A., Cocola-Gant, A., \& Russo, A. P. (2021). Urban tourism and population change: Gentrification in the age of mobilities. Population, Space and Place, 27(1), e2380. https://doi.org/10.1002/psp.2380

Malone, P. (Ed.). (1996). City, capital and water. Routledge.

Marshall, R. (Ed.). (2001). Waterfronts in post-industrial cities. Spon Press.

McCarthy, J. (2003). The cruise industry and port city regeneration: The case of Valletta. European Planning Studies, 11(3), 341-350. https://doi.org/ 10.1080/09654310303634

Meyer, H. (1990). Waterfront renewal, an international phenomenon. The discrete charm of port and city, a seductive combination. In J. Vanreusel (Ed.), Antwerp: Reshaping a city (pp. 67-125). Blondé Art Printing International.

Meyer, H. (1999). City and port: Urban planning as a cultural venture in London, Barcelona, New York and Rotterdam. International Books.

Morris, A. E. J. (2007). Historia de la forma urbana: Desde sus orígenes hasta la revolución industrial [History of urban form: Before the industrial revolution]. Gustavo Gili.

Mosso, E. (1996). Città portuali: L'economia e il território [Port-city: The economy and the territory]. Franco Angeli.

Pellejero-Martínez, C. (2005). Turismo y economía en la Málaga del siglo XX [Tourism and economy in the Malaga of the 20th century]. Revista de Historia Industrial, 14(29), 87-115. https:/doi.org/10.1344/ rhi.v14i29.19607

Perea-Medina, B., Andrade, M. J., \& Rosa-Jiménez, C. (2018). Turismo de cruceros en la interfaz puertociudad Mediterránea: Nueva época del waterfront, con beneficios en un smart destination [Cruise tourism in the Mediterranean port-city interface: A new era of the waterfront with benefits in a smart destination]. Cuadernos de Turismo, 42, 397-419. https://doi.org/10.6018/turismo.42.18

Ponzini, D., \& Akhavan, M. (2020). Star architecture spreads in Europe: Culture-led waterfront projects between 1990 and 2015. In N. Alaily-Mattar, D. Ponzini, \& A. Thierstein (Eds.), About star architec- 
ture (pp. 69-94). Springer. https://doi.org/10.1007/ 978-3-030-23925-1_6

Reinoso Bellido, R. (2005). Topografías del paraíso. La construcción de la ciudad de Málaga entre 1897 y 1959 [Topographies of paradise. The construction of the city of Malaga between 1897 and 1959]. Colegio Oficial de Arquitectos de Málaga.

Rodrigue, J. P., \& Notteboom, T. (2013). The geography of cruises: Itineraries, not destinations. Applied Geography, 38(1), 31-42. https://doi.org/10.1016/ j.apgeog.2012.11.011

Rodríguez Alemán, I. (1984). El puerto de Málaga bajo los Austrias [The port of Malaga during Austria's kingdom]. Servicio de Publicaciones Diputación Provincial de Málaga.

Sennett, R. (1995). Theory. Harvard University Graduate School of Design News (GSD), 1995(Summer Issue), 54-56.

Schubert, D. (2011). Seaport cities: Phases of spatial restructuring and types and dimensions of redevelopment. In C. Hein (Ed.), Port cities: Dynamic landscapes and global networks (pp. 54-70). Routledge.

Schubert, D. (2017). Ports and urban waterfronts. In C.
Hein (Ed.), The Routledge handbook of planning history (pp. 402-417). Routledge.

Shaw, B. (2001). History at the water's edge. In R. Marshall (Ed.), Waterfronts in post-industrial cities (pp. 160-173). Spon Press.

Soriani, S., Bertazzon, S., Di Cesare, F., \& Rech, G. (2009). Cruising in the Mediterranean: Structural aspects and evolutionary trends. Maritime Policy and Management, 36(3), 235-251. https://doi.org/10.1080/ 03088830902861128

Sun, X., Jiao, Y., \& Tian, P. (2011). Marketing research and revenue optimization for the cruise industry: A concise review. International Journal of Hospitality Management, 30(3), 746-755. https://doi.org/10.1016/ j.ijhm.2010.11.007

Vegara, A., \& de las Rivas, J. L. (2004). Territorios inteligentes [Smart territories]. Fundación Metrópoli.

Vilar, P. (1962). La Catalogne dans l'Espagne moderne. Recherches sur les fondements économiques des structures nationales [Catalonia in modern Spain. Research on the economic foundations of national structures]. S.E.V P. E N.

\section{About the Authors}

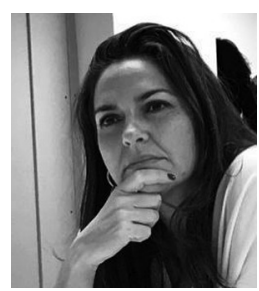

María J. Andrade is Associate Professor in the Architecture Department at the University of Malaga and a Researcher at the Habitat-Tourism-Territory Institute (UMA-UPC) and Centro de Investigação em Arquitetura, Urbanismo e Design (FA-ULisboa). Her research is focused on the relationship between urban public space and transportation infrastructure, focusing on port cities. She is a member of the Scientific Committee of RETE-International Association for the Cooperation between Ports and Cities. https://orcid.org/0000-0002-6104-6569

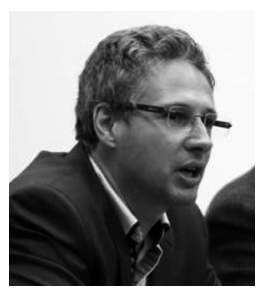

João Pedro Costa is Associate Professor of Urbanism at the Lisbon School of Architecture, University of Lisbon. He is the President of CIAUD-Research Center on Architecture, Urbanism and Design, and the Coordinator of the PhD Program in Urbanism. He develops the research activity in the areas of adaptation to climate change, waterfront rehabilitation, urban and spatial planning policies, and urban morphology. He is currently a Councilman in the City of Lisbon, without executive functions. http://orcid.org/0000-0002-6069-7052

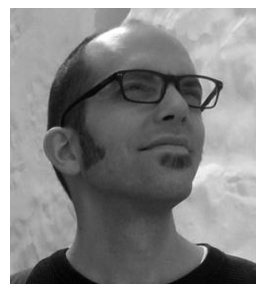

Eduardo Jiménez-Morales, MArch and PhD in Spatial and Urban Planning, is Research Associate at the Art and Architecture Department at the University of Malaga and a Member of UTOPIA (Urbanism, Tourism, Landscape and Architectural Innovation Research Group). His research focuses on tourist cities, studying them from their genealogy to their functional reformulation as medium-sized towns with specific socio-spatial issues. Eduardo is the Author of several high-impact refereed scientific publications and his work as a Scholar and Architect has been recognised by various public and private institutions. https://orcid.org/0000-0003-3417-7990

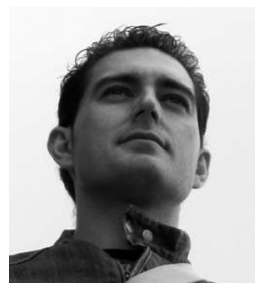

Jonathan Ruiz-Jaramillo, PhD, is a Lecturer in the Architectural Construction Area, where he develops his teaching activity related to structures and construction of buildings. His research field focused on the topics: Conservation and enhancement of architectural heritage; seismic analysis and design of structures; non-destructive testing; and inspection and evaluation (NDT/NDE) of existing buildings. https://orcid.org/0000-0002-2527-9170 